\title{
Cevre Estetiğinde Kullanılan Modellerin Değerlendirilmesi ve Biyofili Bağlamında Yeni Bir Model Önerisi
}

Saeideh ABDOLLAHI*, Hilmi Ekin OKTAY**

Abdollahi, S. ve Oktay, H. E. (2020). Çevre Estetiğinde Kullanılan Modellerin Değerlendirilmesi ve Biyofili Bağlamında Yeni Bir Model Önerisi. YEDİ, 23, 75-86, doi: 10.17484/yedi.626883

Araştırma Makale / Research Article

\section{özet}

İnsan ve doğa arasındaki ilişki, etkileşim ve bağ günümüzün modern toplumunda açık bir şekilde görülmektedir. İnsanlar, tarihin erken dönemlerinde, örneğin avcı toplayıcı oldukları dönemde, doğa içinde gruplar halinde yaşarken, doğaya uyma çabası içinde bulunmuştur. Günümüzde gelişen teknoloji ile birlikte doğayı değiştirmeye ve dönüştürmeye başlayan insanoğlu, bazı araştırmacılara göre antroposen dediğimiz dönemi oluşturmuş ve büyük oranda insan yapımı çevreler içinde yaşar hale getirmiştir

İnsanlar yaşadıkları çevreyi estetik anlamda ve kullanıcı şartlarına uyum çerçevesinde yorumlamaktadırlar. Bu estetik değerlendirme konusu son yıllarda çevre estetiği adı altında çalışılmaktadır. İnsan ile yaşayan canlılar ve/veya canlı benzeri varlıklar arasındaki psikolojik bağ, 'Biyofili’ hipotezinde anlam kazanmaktadır. Biyofili insanların yaşadıkları ve var oldukları doğaya karşı, gerek bilişsel, gerek içgüdüsel olarak doğuştan gelen bir eğilimle, fikirler, yorumlar ve değerlendirmeler üretip onu beslemeleri anlamına gelmektedir. Bu makalede literatür taramaları sonucu çevre estetiği konusundaki araştırmacıların değerlendirdiği beş model incelenmiştir, sonuç olarak eleştirilen veya doğrulanan noktalara göre, biyofili hipotezi bağlamında yeni modeller geliştirilmeye çalışılmıştır.

Anahtar Sözcükler: Doğa, çevre, biyofili, çevre estetiği, çevre estetiği modelleri.

\section{Evaluation of Models Used in Environmental Aesthetics and Proposition of a New Model in the Context of Biophilia}

\section{Abstract}

The relationship, interaction and bond between human and nature are evident in today's modern society. In the early stages of history, for example, when they were hunters and gatherers, while living in groups in nature, they tried to adapt to nature. Today, with the developing technology, human beings began to change and convert nature, and according to some researchers, they formed what we call anthropocene age and made it inhabitable in man-made environments. People interpret their environment in terms of aesthetics and adaptation to user conditions. This issue of aesthetic evaluation has been studied in recent years under the name of environmental aesthetics. The psychological bond between human and living beings and / or similar to living beings gains meaning in the 'Biophilia' hypothesis. Biophilia means that people produce and nurture ideas, interpretations, and evaluations with an innate tendency towards the nature in which they live and exist, both cognitively and instinctively. In this article, five models evaluated by the researchers on environmental aesthetics have been examined as a result of the literature surveys.

Keywords: Nature, environment, biophilia, environmental aesthetics, environmental aesthetics models. 


\section{Giriş}

Çevre; gerek yapı tasarımında gerekse peyzaj tasarımında en önemli verili kaynak olarak, tasarıma şekil veren bileşenlerden birisidir ve oldukça önem arz etmektedir. Başarılı bir tasarımın ancak estetik deneyim açısından tatminkar, çevreyle uyumlu olması ve kullanıcı ihtiyaçlarını karşılaması, onun başarılı sayılmasında yani amacına ulaşmasında önem arz eden bileşenler olarak öne çıkmaktadır. Çevrenin estetik açıdan deneyimlenmesini kendine araştırma konusu yapan çevre estetiği, son yıllarda hızlı bir gelişim gösteren, üzerinde çok fazla durulmamış bir çalışma alanıdır. Ancak gelişimi geçmişe dayanan, tasarım açısından önem arz eden bir çalışma alanıdır. Çevre estetiğinde çevrenin deneyimlenmesine ilişkin çeşitli görüşler sınıflandırılarak çevre estetiği modelleri dediğimiz modeller ortaya konmuştur. Bunun yanında çevre estetiği konusunda insanın estetik deneyimini açıklamaya yönelik birçok teori ortaya atılmıştır. Bu açıdan Wilson'nın ortaya attığı 'Biyofili' (Biophilia) hipotezi önem arz eden ve kullanıcı ihtiyaçlarını da göz önüne alan teorilerden birisi olarak görülmektedir (Wilson, 1984, s. 2). Bu bağlamda yapı ve peyzaj tasarımı açısından çevre estetiği ve kullanıcı tatmininin sağlanması bağlamında biyofili hipotezinin kapsamı ve çıktıları başarılı bir tasarımın gerçekleştirilmesine yönelik en önemli verilerden bazılarını oluşturmaktadır. Bu bağlamda bu çalışma çevre estetiği bağlamında kullanılan modelleri değerlendirerek biyofilik tasarım bağlamında ele alınabilecek bir model önerisi geliştirmeyi amaçlamaktadır. Buna göre 'Çevre Estetiği Disiplininin' tarihçesinden kısaca bahsedilmiş, Carlson'ın (2000; 2009) sınıflamasına göre çevre estetiğindeki mevcut modeller değerlendirilmiş, biyofili hipotezi tanımlanan örnek çalışmalarla açıklanmış ve son olarak ortaya konulmaya çalışılan yeni model tanımlanarak biyofili hipotezi açısından öneminden bahsedilmiştir.

\section{Çevre Estetiği, Çevre Estetiğinin Tarihsel Gelişimi ve Günümüzdeki Durumu}

Çevre estetiği, güzel sanatların dışında, çevreyi ve içindeki öğeleri ele alan, estetiğin bir diğer koludur. Çevrede bulunan, yapay ve doğal elemanlar çevre estetiğinin araştırma nesnelerini oluşturmaktadır. Çevre estetiği çalışma konularına giren yapay elemanlar, çoğunlukla insanın çevreye müdahalesinin sonucu ortaya çıkan sanat dışında kalan kültürel elemanlarken, doğal elemanlar ise doğal süreçler sonucunda kendiliğinden oluşan elemanlar olmaktadır (Carlson, 2009).
Çevre estetiği; yeni bir araştırma alanı olarak, yirminci yüzyılın ikinci yarısından itibaren, felsefe alanının içerisinde, detaylı şekilde çalışılmaktadır. Çevre estetiği, her ne kadar yeni bir araştırma alanı olsa da bu alana dair kavramlar, yirminci yüzyıl öncesinde gündeme gelmiş ve bazı aydınlanma düşünürleri tarafından üretilen düşünceler sayesinde temelleri atılmıştır (Carlson, 2009). Çevre estetiğinin kökenlerine dair ilk düşünceler 18. yüzyılın öncesine kadar geri götürülebilmektedir. Doğanın bir estetik obje olarak beğenilmesi 1336 tarihinde Petrarca'nın Ventoux dağına tırmanıp, manzaranın keyfini çıkarmaktan bahsettiğ yazılarına kadar geri götürülebilmektedir (Carlson ve Lintott, 2008).

Doğanın estetiği ile ilgili ilk ana akım felsefe gelişimi 18.yy.'da meydana gelmiştir. Bu dönemde estetik deneyimin merkezinde, obje olarak sanat yerine doğa ele alınmaya başlamıştır (Carlson, 2009, s. 2), aynı zamanda 'çıkarsızlık' kavramı bu dönemde gelişmiştir ve estetik deneyimin merkezcil kavramlarından biri haline gelmiştir (Carlson ve Berleant, 2004, s. 11-42; Carlson ve Lintott, 2008, s. 1-22; Carlson, 2009, s. 2). Çıkarsızlık kavramı 'kişisel ilgi veya kaygılardan farklı bir estetik nosyon' olarak tanımlanmak ve karakterize edilmek amacıyla Earl of Shaftesbury tarafından ortaya konmuştur (Carlson, 2009, s. 2).

Geç 18.yy.'da resimsi idesi hakkındaki teoriler, William Gilpin (1792), Uvedale Price (1794) ve Richard Payne Knight (1794) gibi isimlerin kaleme aldıkları yazıların tesiriyle Batı düşünce dünyasında popülerlik kazanmıştır (Carlson, 2009, s. 4). Hegel'in 'sanat, doğaya nazaran 'Mutlak Tin'nin' en yüksek ifadesidir' felsefesiyle estetiğe yaklaşım gerçekleştirmesinden hareketle, 19.yy.'da doğanın estetiğinin felsefi çalışmasının düşüşe geçtiği söylenebilir.

20.yy.'ın ilk yarısında filozoflar ve felsefeciler, doğanın estetiğini çoğunlukla görmezden gelmişlerdir, bu dönemde filozoflar estetiği yoğun bir şekilde tartışmış olsalar da, doğanın estetiği hakkında derin düşünceler üretilmemiştir, bu dönemde araştırmacılar ağırlıkla insan ürünü olan ve sanat estetiği ile ilgili konulara odaklanmıştır, yani felsefede estetik ile ilgili düşünceler ağırlıkla sanat bağlamında üretilmiştir. Buna karşılık, Hepburn (2004) bu dönemde güzelliğe ilgi çekmekle, sanat dünyasının da ötesindeki dünyanın deneyimlenmesine dair anlamlı felsefi soruşturmalar yapmış, felsefenin doğanın estetiğine ilişkin ilgisini yenilemiş ve çevre estetiği ile gündelik yaşamın estetiğinin temellerini atmıştır (Carlson, 2009, s. 5). 20.yy.'ın çevre estetiği 
Hepburn'ün (2004) makalesinden sonra bambaşka bir seyir izlemeye başlamıştır.

20.yy.'da Hepburn'ün makalesinden sonra birçok düşünür çevre estetiği ile ilgili araştırmalara başlamıştır ve bunlar arasında Carlson (1979), Berleant (1992), Saito (1999), Sepänmaa (1986) öne çıkan isimlerdir, bu bağlamda yapılan birçok araştırma insanın doğal ve/veya insan yapısı çevreler içinde yaşadığı estetik deneyimin sorgulanmasına odaklanmaktadır. Bazı araştırmacılar, çevre ile insanının bütünselliğinden hareket ederek, katılım yaklaşımıyla çevre ve insanı tek bir bütün içinde görmüş ve bu bağlamda çevre içinde katılımla estetik deneyimin gerçekleştiğini (Berleant, 1992) savunmuştur. Diğerleri de estetik deneyimin çevremiz hakkındaki bildiklerimizden ve bilgimizden kaynaklandığını (Carlson, 1979) savunmuş, bunun yanında gündelik yaşam deneyimlerinin en siradan ve en basitlerinin bile estetik ile ilişkili olduğunu savunanlar da zaman içerisinde ortaya çıkmıştır (Saito, 1999). Farklı yaklaşımların kümelendiği modeller bu bağlamda çevrede yaşanan estetik deneyimin anlaşılmasında önem arz etmektedir. Bu çalışmada Carlson'ın (2009) sınıflandırdığı beş farklı model bağlamında çevre estetiği değerlendirilmeye çalışılmıştır.

\section{Çevre Estetiğinde Kullanılan Mevcut Modeller}

Çevre estetiğine ilişkin farklı yaklaşımlar, tanımlanmış modeller kapsamında değerlendirilmektedir. Bu yaklaşımlar, köken olarak temelde iki paradigmadan türemektedir, daha önce belirtildiği gibi estetik 19.yy.'da Hegel'in de etkisiyle sanat merkezi bir karakter kazanmıştır, bu bağlamda estetiğe yaklaşan düşünürler sanatı ve sanat objelerini, estetiğin temel göstergeleri olarak almakta, çevreye ve doğaya da sanat objesine yaklaşıyormuş gibi hareket etmektedir. Bu yaklaşım tarzı, sanat kökenli olduğundan, çevre estetiğinde kullanılan bazı modellerde sanattan yola çıkan bir paradigmada kendini göstermektedir. Ancak, özellikle Hepburn'ün makalesinden sonra çevre ve doğayı odağa alarak yaklaşan düşünürler, çevre estetiğinin kendi özgül durumlarını göz önüne alarak, çevre estetiği özelinde yeni modeller ve yaklaşımlar geliştirmişlerdir (Carlson, 2009, s. 11).

Carlson (2009) çevre estetiğinde beş yaklaşımdan bahsetmektedir. Bu yaklaşımların ikisi (Obje Modeli, Peyzaj Modeli), klasik sanat estetiği bağlamında ortaya çıkmış ve çevre estetiğine uyarlanmıştır, diğer ikisi ise (Şoven İnsan Estetiği Modeli, Katılım Estetiği Modeli), çevre estetiği geleneği içinde doğmuştur. Son model olarak adlandırılan doğal çevre modeli ise bilişsel çevre estetiğinin vardığı son noktada gelişmiştir (Carlson, 2009). Yakın bir geçmişte geliştirilen bu model, çevre estetiği içinde çıkan fenomenolojik yaklaşımların, bilim içinde gelişen ampirik yaklaşımlarla olan mesafesini kapatmak için, bilişsellik bağlamında, bilişsel bir çevre estetiği modeli olarak ortaya çıkmıştır. Bu bölümde çevre estetiğine dair felsefi yaklaşım modelleri Carlson'ın (2000; 2009) tanımlamalarından yola çıkılarak aktarılmıştır.

Sanat eseri bağlamında ilk model olarak ‘Obje Modeli’ni tanımlamak gerekirse, 'Obje Modeli’ sanatta belirli bir fiziksel objeyi, biçim, ifade, tasarım ve diğer özellikleriyle estetik olarak takdir edilmesini kapsamaktadır. Ancak objeyi tekil bir nesne olarak görür, çevresiyle ilişkisini, yani bağlamı göz önüne almaz. İnsanlar doğada ilginç bir formasyonu olan herhangi bir kayayı da obje modeli doğrultusunda estetik olarak takdir edebilir. Bu modele göre, bahsi geçen estetik takdiri gerçekleştirmek için, o kaya parçasını gerçekten veya hayali olarak çevresinden çıkarıp ve soyutlamak gerekmektedir (Carlson, 2009, s. 25). Bu durumda, doğa veya çevre değil, sanatta olduğu gibi sadece obje estetik olarak deneyimlenecektir. Bu açıdan yaklaşıldığında, model bağlamında yaşanan deneyim bir çevre estetiği deneyimi değil, sanat estetiği deneyimi olacaktır (Carlson, 2000, s. 26).

Bu kayayı bağlamından koparmakta bir bakıma 'problemli bir durumun' önünü açmaktadır (Carlson, 2009, s. 25). Çünkü onu oluşturan doğal ve çevresel "bağlamından koparmak" onu deneyimlememizi indirgeyecektir. Bu tarz bir değerlendirme her obje için geçerli bir durum değildir. Örneğin bir sanat eseri tablosunu biz çevresinden bağımsız değerlendirebiliriz ve bu yapılan estetik değerlendirme de herhangi bir sorun teşkil etmez. Ancak o tablo sadece bir tablo olarak değerlendirilecektir ve bu tabloyu saran çevrenin olup olmaması bizim estetik değerlendirmemizi fazla etkilemez ama bir kayayı çevresinden ayırarak değerlendirmek pek mümkün görünmemektedir. Bu bağlamda obje modeli sanat eserleri için başarılı ve geçerliyken, doğa ve çevrede boşluğa düşmektedir. Çünkü, kaya örneğinden devam edersek, o kayayı estetik deneyimin objesi yapan ve onun 'dokusunu, sertliğini, haşinliğini ve sağlamlığını gösteren' onu saran çevresi ve oradaki peyzajın bağlamının özellikleridir, örneğin denizin kayaya vuran dalgaları, rengi, sakinliği ve yansımaları o kayayı estetik yapan ve ona kimlik kazandıran bir çevredir (Carlson, 2009, s. 26).

Çevreden ayrı ve tekil bir şekilde estetik bir değerlendirme veya yargı yapılsa bile, bu değerlendirmenin 
kalite ve doğruluk payı güvenilir olmayabilir. Çevre ve içindeki objeler yapboz parçaları gibi düşünmek mümkündür, bu şekilde hareket edildiğinde yapbozun tüm parçaları yan yana olduğunda anlam kazandığını söylemek mümkündür, tek bir parçasını diğerlerinden ayırıp değerlendirme yapıldığında ise deneyimin değeri tek bir parça kadar olmaktadır ve ondan anlam çıkarıp ve değerlendirmenin mantıklı ve/veya bütüncül bir estetik deneyim olduğunu söylemek güçtür.

Klasik sanat estetiği bağlamında ortaya çıkan başka bir model ise 'Peyzaj Estetiği' modelidir. Bir bakış açısına göre; Peyzaj 'Hakim Manzara' (Prospect) anlamına gelir ve bu hakim manzara belirli bir noktadan manzara ile araya mesafe koyularak izlenebilir (Tuan, 1974). Carlson'a göre peyzaj tabloları sıklıkla bu hakim manzarayı temsil etmektedir ve 'Peyzaj Modeli' 'de bu akım ile yakın ilişki içindedir (Carlson, 2009, s. 26). Peyzaj tablosu estetik olarak taktir edilirken odak tipik olarak ne gerçek obje (tablo), ne de temsil edilen obje (hakim manzara) 'dir. Bu ikisinin ötesinde, obje ve obje özelliklerinin temsilinin üzerindedir. Estetik taktirin vurgulaması hakim manzarayı simgelerken önemli rol oynayan, çizgi, renk ve genel tasarım gibi görsel niteliklerin üzerindedir. Bu özellikler peyzaj resminde önemli rol oynarlar ve peyzaj modelinin odağını oluştururlar. Peyzaj modeli, çevre estetiğinde de doğayı bir peyzaj tablosu gibi algılamayı ve taktir etmeyi teşvik etmektir.

Peyzaj modeli 18.yy.'daki önemli çevre estetiği kavramlarından olan resimsi (pitoresk) ile yakın ilişki içerisindedir. Resimsi İngilizce'de resme benzeyen, resim olabilir nitelikteki doğa parçalarının estetik deneyimlenmesinde kullanılan bir kavramdır. Bu kavramda doğal dünyanın estetik deneyimlenmesi bu doğanın manzaralara bölünerek her bir manzaranın bir peyzaj tablosuymuş gibi deneyimlenmesidir (Carlson, 2009, s. 2; Carlson, 2009, s. 27).

Carlson (2009) modelin bakış açısı nedeni ile doğayı iki boyutlu statik bir görüntüye indirgediğini ve bundan dolayı doğanın deneyimlenmesinde yaşanan birçok deneyimi dışarıda bıraktığını savunur. Zaman boyutu da göz önünde bulundurulduğunda, bu modelde 4 boyutlu bir doğa deneyimi, iki boyutlu bir doğa deneyimine indirgenmektedir, bu nedenle direk olarak doğaya maruz kaldığımızda yaşadığımız heyecan, korku, merak, huzur, sevinç, mutluluk, doğadaki korku yaratan seslerin verdiği tatlı gerginlik, zamanın önemi, gecenin verdiği heyecan, korku ve gündüzün verdiği huzur, mutluluk ve bunlara benzer diğer hislerin deneyimi bu değerlendirmenin dışında kalmaktadır. Peyzaj modelini, modeller konusunda hiçbir bilgi sahibi olmayan bir insanın bile çocukluğundan itibaren doğal olarak farkında olduğu, tecrübe edip ve deneyimlediği bir model olarak görmek mümkündür. Çevre estetiği geleneği içinde doğmuş olan modellerden birisi 'Şoven İnsan Estetiği Modeli' ‘dir. Bu model estetik olmayan (Nonaesthetic) model olarak da bilinmektedir (Carlson, 2000). Modelin temel kabulü 'doğaya ilişkin estetik deneyimin mümkün olamayacağı' ve 'doğaya yönelik yaşanan deneyimin estetik çerçevesinde’ değerlendirilemeyeceğidir (Carlson, 2000; 2009). Bu yaklaşım sanatın geleneksel olarak estetik deneyimin ana nesnesi olduğunu ve sadece sanatın estetik deneyime neden olacağını kabul eder, ancak; doğa doğal olduğu için ve sanat gibi insan yaratısı olmadığı için estetik olarak deneyimlenecek bir obje niteliğinde değildir (Carlson, 2009). Buradaki şoven terimi, insan yapımı nesneler dışındaki nesneleri estetik olarak değerlendirmenin mümkün olmadığını savunan, estetiğin insanla sınırlı olduğunu ve çoğunlukla sadece sanat eserlerinin estetik olarak değerlendirilebileceğini savunan katı tutumu adlandırmak amacıyla kullanılmıştır. Bu görüşün savunucularından biri Robert Elliot'tur (Carlson, 2009). Carlson (2009) Elliot'ın estetik değerlendirmedeki yargı unsurunun onu çevresel değerlendirmeden farklılaştırdığını ve sanat objelerinin değerlendirilmesinde objenin yaratıcısının niyetleri doğrultusunda yargılanması ve açıklanmasının, onu belirli sanat gelenekleri ve dönemleri ile ilişkilendirmenin olduğunu ama doğanın sanat olmadığından dolayı bu niteleme ve değerlendirmelerin objesi olamayacağını savunmaktadır.

Genel anlamda bu model ve temel aldığ fikirler değerlendirildiğinde; bir sanatçı sanat eserini yaratmak için genelde iki yol izleyebildiği görülmektedir. Bu yollardan birincisi doğadan, doğadaki elemanlardan ve dokulardan ilham alarak ve bu ilhamları duyguya, fikre, yaratıcılığa döküp ve görsel bir sanata çevirerek bir sanat eseri yaratmasıdır ki burada sanat eserinin kökeninde gene istemsiz doğanın, istemli insan tarafından dönüştürüldügü görülmektedir. Bunlardan ikincisi ise, bir fikirden, düşünceden, hayatta yaşanan olaydan veya hislerinden yola çıkarak bir sanat eseri yaratılması eylemidir. Burada yaşanan olay ve olgular yine irade dışında gerçekleşmekte ve istemsiz doğa yine bir iradi güç tarafından dönüştürülmektedir.

Çoğunlukla sanatla ilgilenenlerin, en acemisinden profesyoneline kadar, yarattıkları eserlerin ilham kaynağı ve sebebi sorgulandığında genelde açıklamalarının sonu 
doğaya dayandığı gözlemlenmektedir. Örneğin: bir ressam doğayı görmezse, taktir edip ona özenmezse, izlemekten zevk almazsa, onu hissedip sanatçı gözüyle bakıp kendi içine taşımazsa nasıl bir sanat eseri yaratabilir sorusu sorgulamalar sırasında insanın karşısına sıkça çıkmaktadır. Başka bir tabirle şu soruyu sormak yerinde görünmektedir: Şoven insan estetiği modelindeki estetiğin tek nesnesi olarak görülen sanatın ilham kaynağı nedir? Bu sanattaki fikirler ve yaratıcılıklar ilham kaynağı anlamında nereden beslenmektedir? 0 sanatın var oluşuna sebep olan düşünce nedir? Bu düşüncenin kökü nereye dayanıyor? Bu sorular estetik deneyimin bir anlamda sanatta dönüştürülmüş bir doğa deneyimi olduğu cevabıyla yanıtlanabilir. Bundan dolayı, bu modelin temel fikrinin sanatı doğadan ayrı görmesi, dışlaması, sadece ve sadece sanatı estetik değerlendirme ve yargıya layık görmesi, bu bakımdan eksik kalan, temeli oluşturulmamış görüşler olarak görülebilmektedir.

'Katılım Estetiği Modeli' Berleant (1992) tarafından geliştirilmiştir. Bu model sanat kökenli modellerden olan obje modelinin sınırlılıklarına odaklanarak doğal çevrenin, çevre boyutuna odaklanmaktadır (Carlson, 2009, s. 30). Özne ve nesnenin sınırsızlığından, birbirine geçmiş olmasından beslenmektedir. Klasik özne-nesne dikotomisini kabul etmeyen model, çevrenin bir bütün olduğundan bahseder ve 'algılayanında çevrenin ayrılmaz bir parçası olduğunu' savunur (Carlson, 2009, s. 30). Buradan hareketle sanat kökenli modellerin, yalıtılmış uzaklaştıran ve nesnelleştiren bir durum yaratması nedeniyle özneyi ve doğal objeyi içinde bulundukları bağlamdan soyutladığını ve bu soyutlamanın obje ve öznenin ait olduğu bağlamda yani çevreyle birlikte yaşayacakları daha uygun, daha doğru bir estetik deneyimin önüne geçtiğini savunmaktadır (Carlson, 2009, s. 31). Bundan dolayı katılım estetiği soyutlamanın yerine katılımı, uzaklaşmanın yerine tam olarak içeride olma (immersion) ve nesnellik yerine öznelliği koyarak doğanın estetiğine katılımcs bir alternatif önermektedir (Carlson, 2009). Burada algılayan özne dışardan bakan ve dışarıdan yorumda bulunan bir pozisyonda değil, tam tersine algıladığı nesne ile bütünleşen ve nesne ile öznenin arasındaki ikiliği ortadan kaldıran bir katılımcıdır (Berleant, 1992).

Bir sanat eserini veya doğa nesnesini estetik olarak deneyimlemede ve değerlendirmede her zaman katılım estetiği modeli geçerli olmayabilir, bazı estetik değerlendirmelerde tabi ki insanın kendisini o çevrenin, o eserin bir parçası olarak görmesi onun daha uygun bir estetik değerlendirme yapmasına yardımcı olabilmektedir. Ama bazı durumlarda, öznenin tercihi; estetik değerlendirmeyi, öznenin kendisini o nesneden, o eserden uzaklaşarak ve araya mesafe koyarak yapılmasindan yanadır ve bu olguda değerlendirmesi yapılacak esere göre değişebilen bir durumdur. Bazı soyut sanat tablolarının daha sağlıklı bir estetik değerlendirmesi yapılabilmesi için eserle katılımcı arasında mesafe olması gerekebilir ve katılımcının kendisini o eserin bir parçası olarak görmesi gayet zor ve bazen imkansız bile olabilmektedir. Doğada, insanın özellikle kalabalık mekanlarda, kendini yalıtma öznelliğini yaşama isteği olan durumlar olabilir, bu durumlarda estetik deneyim kendi içsel deneyimlerinin doğaya mesafe konularak gerçekleştirilmesinde oluşabilir. Bu durumda doğadaki herhangi bir nesne bir durum estetik deneyimin kökenini oluştursa da öznelliği tercih eden bireyler aradaki etkileşimi etkileyen parazitleri ortadan kaldırmak için o nesne ya da durumun zihinsel imgesiyle bu deneyimi yaşayabilmektedir.

Mevcut modeller bağlamında incelenecek olan son model ise 'Doğal Çevre Modeli' 'dir. Bu model Carlson tarafından geliştirilmiştir. Çevre estetiğine sanattan devşirilmiş olan obje modeli ve peyzaj modeline bir tepki olarak ortaya konulmuştur (Carlson, 2000). Yine de model sanattaki bazı estetik yaklaşımları çevrenin ve doğanın estetik deneyimlenmesinde yol gösterici olabileceğini inkar etmemektedir (Carlson, 2009). Sanat ürünlerinin estetik deneyimlenmesinde sanat eserinin gerçek doğasına ilişkin bilginin, eserin beğenilmesinde zaruri olduğunun altını çizen Carlson (2000), bu noktada Picasso'nun yapmış olduğu Guernica (1937) tablosunu örnek verir (Carlson, 2009, s. 11). Bu tablonun estetik beğenisinde bunun bir kübist veya neo-kübist bir eser olduğunun bilinmesinin, eserin estetik değerlendirilmesinde önemli olduğunu ve bu estetik değerlendirmenin de kübizm akımı hakkında sahip olunan bilgiler çerçevesinde gerçekleştiğini örnek verir (Carlson, 2000). Bunun yanında bir sanat eserinin ait olduğu tür kadar yaratıcısı ve 'yaratıcısının niyeti' hakkında olan bilgide estetik deneyimle ilişkilidir (Carlson, 2009). Buradan hareketle doğanın veya çevrenin belirli bir yaratıcısının olmadığının olgusunun doğa hakkında hiçbir şey bilmediğimiz anlamına gelmediğinin de altını çizer (Carlson, 2009). Bunun için doğa ile ilgili disiplinlerin ekolojinin ve jeolojinin sağladığ bilginin doğanın uygun şekilde estetik deneyimlenmesi için bizi donattığını savunur ve bu yüzden doğal ve çevresel bilimleri doğanın estetik deneyimlenmesinde merkezcil bir 
öneme sahip görür (Carlson, 2009).

$\mathrm{Bu}$ model tıpkı sanatın estetik deneyimlenmesinde, sanat eserini nasıl görüyorsa doğayı da çevrenin estetik değerlendirmesi ne ise, o olarak görmeye çalışmakta görünmektedir. Onu doğal ve çevresel olarak deneyimlemekte ve bunun gerçekleşmesi için de deneyimleyenin; doğanın ne olduğuna ilişkin biyoloji, jeoloji ve ekoloji gibi fen bilimleri tarafından sağlanan bilginin, doğanın doğrudan estetik deneyimlenmesinde ve bu deneyimleme sırasında öznenin doğadan kopmaması için önemli olduğunu savunmaktadır (Carlson, 2000). Çalışmalar doğadaki unsurlara karşı korkumuzun, silah, araba çarpması gibi insan yapımı etkenlere karşı duyduğumuz korkudan daha derin ve içgüdüsel olduğunu ortaya koymuştur (Van den Berg, Hartig, ve Staats, 2007). Giderek bozulan insan doğa ilişkisinden doğan, doğanın dengesinin olumsuz etkilenmesi ve birçok çevre sorununun meydana gelmesini düzeltme amaçlı ve toplumun çoğunun doğal çevre modeli bağlamında estetik deneyim yaşaması için, insanın içgüdüsel kodlamalarının nasıl kırılacağının araştırılması önem arz etmektedir. Doğal çevre modelin savunduğu noktalardan biri 'doğa ile ilgili disiplinlerin ekolojinin ve jeolojinin sağladığı bilginin doğanın uygun şekilde estetik deneyimlenmesi için bizi donattığı’ düşüncesidir.

İnsanoğlu ortaya çıktığı günden itibaren doğaya maruz kalıp ve onun ekolojik ve jeolojik sistemlerinin profesyonel eğitimini almadan, doğayı yaşayarak, tecrübe edip, öğrenmeye çaba gösterdiği görünmektedir. Doğa ve çevre her insanın varoluş tarzından dolayı algılayabileceği ve yorumlayıp, değerlendirip, yargılayabileceği bir bütündür. Bunlara dayanarak doğanın estetik olup olmadığını değerlendire bilmek için herhangi bir jeolojik veya ekolojik bilginin gerekli olduğu düşünülmemektedir. Bilgi kapsamında doğayı yorumlamak, doğal olarak daha profesyonel ve bilişsel bir yoruma yol açmaktadır ama profesyonel bilginin olmaması durumunda yorum hakkı yine insanlarda saklı kalmakta görünmektedir. Küçük bir çocuk bile doğaya maruz kaldığında onu algılayıp ve hisleriyle, hareketleriyle, tepkileriyle kendince yorumlayabilme yeteneğine sahip olduğu düşünülmektedir. İnsanlar doğanın bir parçasıdırlar ve bu sebepten doğa ile insan arasında müşterek kodların var olduğu öne sürülebilinir.

\section{Biyofili Hipotezi}

Sanayileşme ve kentleşme sonrası, teknolojinin de hızla hayata yayılması sonucu, insanlar doğaya zarar vermeye başlamış ve çevre sorunları artmıştır. Çevre sorunlarının arttığı bu dönem, antroposen ve/veya insan çağı olarak adlandırılmıştır (Anthropocene, t.y.). Antroposen çağında, hızlı ekonomik büyümenin yarattığı çevre sorunları ve atıkları, ozon tabakasının incelmesi, iklim değişiklikleri, zirai ilaçların ve kimyasalların yarattığı ciddi yan etkiler, küresel ısınma, nükleer enerji kullanımının yol açtığ tehditler, fosil yakıt rezervlerinin bitmesi ve yok olması, en önemli çevre sorunları olarak sayılabilir (Heywood, 2007, s. 321-322). Çevre koruma düşüncesi veya çevreci düşünce antroposen çağı ve bu dönemdeki tahribata karşı bir tepki olarak doğmuştur. Sanayileşme ve kentleşmenin bozduğu insan ve doğa birlikteliği ile ilişkisini yenilemek adına erken dönemde 'doğaya geri dönüş’ sloganıyla romantik bir çevre koruma düşüncesi ortaya çıkmıştır (Dobson, 1993, s. 216). Çevreci yaklaşımlar zaman içinde daha da gelişmiştir ve genel anlamda günümüzde birçok çevreci yaklaşımın sürdürebilirliği hedeflediği söylenebilir. Erken dönemlerde bahçe-kent anlayışı ve son dönemlerde yeşil tasarım, ekolojik tasarım ve biyofilik tasarım, sürdürebilirlik amacını taşıyan ve insan-doğa ilişkisine vurgu yapan yaklaşımların içinde yer almaktadır. Bahçe-kent anlayışı, yeşil tasarım ve ekolojik tasarım, insan ve doğa arasındaki ilişkiye, insanların ihtiyaçları doğrultusunda malzeme ve fiziksel odaklı yaklaşırken, biyofilik tasarım insan ve doğa arasındaki ilişkinin duygusal yönüne odaklanmaktadır.

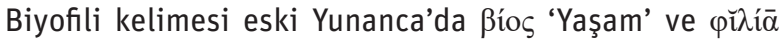
'Sevgi' terimlenrinden gelmektedir (Gizushka özgün Türkçe blog, t.y.), biyofiliyi ‘yaşama karsı duyulan sevgi’ olarak da tanımlanabilir. Biyofili terimi ilk defa Psikolog Eric Fromm tarafından ortaya konulmuştur. Fromm biyofiliyi 'yaşam ve canlılara karşı duyulan güçlü bir sevgi’ olarak tanımlamıştır (Genç, Selçuk, ve Beyhan, 2018, s. 363-364). İnsanın doğa ile teması sürdürme eğiliminin endikasyonları tarih boyunca görülebilir. Eski Mısır soylularının evleri, Pers yerleşimleri ve ortaçağ Çin köylerinin hepsi, insanların doğa ile teması sürdürmek için önemli ölçüde uzadıklarını? gösteren geniş ve ayrıntılı bahçelerle işaretlenmiştir (Ulrich, 1993, s. 73-137).

Biyofili kavramı 1984 yılında ilk kez Amerikalı biyolog ve evrim teorisyeni olan Edward O.Wilson'ın 'Biophilia' (1984) başlığını taşıyan kitabında geliştirilmiş ve tanımlanmıştır. Wilson'ın Doğanın Gizli Bahçesi (In Search Of Nature) isimli çalışmasında biyofili kavramını 'insanın yaşama ve yaşam benzeri süreçlere karşı olan doğuştan gelen eğilimi’ olarak 
tanımlamıştır (Wilson, 1996, s. 3). Başka bir deyişle 'insanın canlı ve canlı benzeri süreçlerle doğuştan gelen bir ilgisinin olduğuna' da vurgu yapmıştır. Bu durumda biyofili kavramını insanların doğaya ve doğadaki canlılara karşı doğuştan gelen duygusal yakınlığı ve içgüdüsel bağı olarak ele almak mümkündür.

Sonraki dönemlerde Kellert ve Wilson tarafından biyofili kavramı, 'Biyofili Tasarımı' olarak mimarlığa taşınmıştır. Kellert ve Wilson 2005 yılında biyofili hakkındaki düşüncelerini ‘Building For Life’ isimli çalışmalarıyla mimarlık ortamında var etmişler ve 'Biyofilik Tasarım' kavramını ilk defa bu kitapta tanımlamış, daha sonra 2008 yılında ‘Biyofilik Tasarım' kavramına özel olan ‘Biophilic Design' adlı kitabı diğer araştırmacıların makalelerinden de destek alarak derlemişlerdir (Çorakçı, 2016; Heerwagen ve Orians, 1993). Onların çalışmalarına göre biyofilik tasarım 'insanın yaşadığı yapılı olan çevreye doğal elemanlar ve unsurların getirilmesi ve insan-doğa ilişkisinin sürdürülmesi' olarak tanımlanabilir.

Biyofilik tasarımını destekleyenlerin üzerinde durdukları en önemli nokta, insanın evrimsel süreci içerisinde hayatta kalma çabası, üretme başarısı ve yaşamla kurduğu bağıdır, bu bağ doğaya yakınlık hissi olarak geçerli olmaktadır ve her insanın taşıdığı ortak bir duygudur. (Bayraktaroğlu, 2014, s. 35; Brown, Barton , ve Gladwell, 2013; Ikei, Komatsu, ve Song, 2014: Nieuwenhuis, Knight, ve Postmes, 2014). Biyofili kavramı doğal elemanlar ile olan etkileşim ihtiyacının duygusal yönüne dikkat çekmektedir. Biyofili tasarımının içerdiği doğa temelli özellikler: yerellik, doku, denge, devamlılıktır. (Bayraktaroğlu, 2013, s. 47).

Biyofili ile ilgili son dönemlerde birçok çalışma yapılmaktadır. Yapılan bu çalışmalar, araştırmanın bu bölümünde değerlendirilmeye çalışılmıştır. Bu çalışmalardan birisi, Zhan ve arkadaşlarının yaptığı ve kentleşmenin hızlı olduğu Çin'de çocukların doğayla olan temasları sonucu biyofili, biyfobiya ve koruma tutumlarının derecesi ölçüldüğü bir çalışmadır. Bahsedilen çalışma kapsamında, köy okulunun da içerisinde bulunduğu farklı kentleşme derecelerine sahip okullarda, 9-10 yaş arası öğrencilere ne sıkıkta açık hava etkinliklerine katıldıkları sorulmuştur. Bu soru çocukların doğayla olan temaslarının ne sıklıkta olduğunu ölçmeye yarayan bir indikatör olarak kullanılmıştır. Sonuç olarak köy okulundaki çocukların, kent okulundaki çocuklara göre daha çok doğa ile temasta oldukları belirlenmiş ve bu temas çocukların hayvanları, yabani hayatı ve biyo-çeşitliliği koruma isteklerinin biyofilik tutumu vasıtasıyla arttığını gösterdiği savunulmuştur (Zhang, Goodale, ve Chen, 2014).

Rosley vd.'in yaptığı çalışmada 5 ekolojik manzara fotoğrafı, uzman olanların ve kullanıcıların benzer kişisel özellikleri üzerinden, bu kişilerin estetik kalite değerlendirilmeleri saptanmaya çalışılmıştır. Sonuç olarak uzmanların ve kullanıcıların karmaşıklık, doğallık ve okunabilirlik kavramlarını görsel kavramlar olarak daha baskın bir şekilde onayladıkları ortaya konulmuştur (Rosley, Abdul Rahman, ve Lamit, 2014). Buradaki doğallık kavramının uzman olan ve kullanıcıların ortak olarak onaylaması ise bir anlamda insanların uzman olmalarına bağlı olmadan, içgüdüsel anlamda doğallığı aradıklarının ispatı olarak okunabileceği ve her ne kadar estetik aracılığı ile olsa da insanların sosyal oluşumlarda biyofiliyi dahil etme istekleri olduğu şeklinde okunabilir. Benzer bir çalışmanın üniversite iç mekanlarında ve kampüsünde uygulandığında sonuçlar; daha iyi, yaratıcı, hareketli, yenilikçi, mahir, yetenekli ve psikolojik, sosyal, entelektüel, fiziksel anlamda daha sağlıklı ve olumlu öğrencilerin eğitim alabileceğini destekler nitelikte çıkmıştır (Abdelaal, 2019). Biyofili kavramının çözüm olarak kullanılması sadece eğitim muhitleriyle sınırlı kalmayıp ve iş yerlerinde de uygulanmaya ve etkileri ölçülmeye çalışılmış ve araştırmada nicel anlamda iş yerindeki biyofili tasarımının bileşenleri olarak yeşillik ve gün ışığının iş performansı verimliliğinin üzerindeki etkisi ölçülmeye çalışılmıştır. Sonuç olarak gün ışığı ve yeşilliğin biyofili tasarımı bileşenleri olarak sağıık, performans, yaratıcılık ve refah anlamında pozitif bir gelişme sağladığı öne çıkmıştır (Sanchez, Ikaga, ve Sanchez, 2018).

Bu çalışmalar insanların farklı ortamlarda dahi biyofilik tasarıma karşı ne kadar hassas olduklarını gösterir niteliktedir. Bir anlamda günümüz yaşam koşullarının ağırlığının gündelik yaşamı çevreleyen mekanlarda biyofilinin eksikliğinden geldiği savunulabilir. Bu anlamda çevre estetiği bağlamında biyofiliyi değerlendirmek daha bir önem arz etmektedir.

\section{Model Önerisi ve Modelin Tanımı}

Carlson'ın (2009) betimlediği tüm modeller incelenip, avantaj ve dezavantajlarının değerlendirmesi yapıldıktan sonra, sonuç olarak bu modellerin bazılarının uzman/ kullanıcı fark etmeksizin tüm estetik deneyim tiplerine hitap edemeyebileceği fark edilmiş ve bu bağlamda sorgulamalar yapılmıştır. Bu modellerden kimisi bazı uzmanlık bilgilerine sahip insanlar tarafından kullanılabilse de tamamlanması gereken bazı eksiklerinin olduğu ve bundan dolayı her normal 
kullanıcının deneyimine yansıyamayacağı gözlemlenmiştir. Bunun üzerine bu modeller tüm insanların kullanımına açık olması için, bir taraftan genelleştirmek gerekirken, diğer taraftan detaylı bilgilere sahip, derinlemesine ve sistematik eğitim almış insanların kullanması için özelleştirmek amaçlı iki model önerilmiştir.

1)İçgüdüsel İnsan Kodlarına Bağlı Özgür Çevre Estetik Modeli

\section{2) Profesyonel Çevre Estetiği Modeli}

İçgüdüsel İnsan Kodlarına Dayalı Özgür Çevre Estetik Modeli; direk doğaya hitap eden ve profesyonel bir bilgiye ihtiyaç duymayan bir çevre estetiği modelidir. Bu modele göre insanın yaradılış tarzından dolayı ve doğa ile aynı kodları taşıdığından dolayı, tüm insanlar kendi düşünceleri ve deneyimlerine göre özgürce bir değerlendirme ve yargılama yapabilmektedirler. İnsanlar deneyimleri ve içgüdüsel kodlarına dayalı bilgiyi kullanarak ve herhangi bir profesyonel bilgiye gerek duymadan, estetik değerlendirmelerini yapabilmekte ve bu değerlendirmeler her türlü arka plandan bağımsız gerçekleşmektedir. Bu model değerlendirmesinde insanların yaşam tarzları, ilgi duydukları farklı dallar, bakış açıları, hayattaki deneyimleri ve zevkleri değerlendirmelerin kalitesini etkilemektedir, ama bu farklılıklar onları özgürce bir estetik değerlendirme yapmaktan mahrum bırakmamaktadır.

Profesyonel Çevre Estetiği Modeli, değerlendirilecek çevre veya nesneyle ilgili, normal seviyeden profesyonel seviyeye doğru bilgi sahibi olmayı gerektiren bir modeldir. Profesyonel anlamda bir bilgi, insanların daha kaliteli ve profesyonel bir değerlendirme yapmasına yardımc olmaktadır. Bir kübizm veya bir soyut tablo ve sanat eseri değerlendirmesinde bu iki teknik ile ilgili insanların bilgisi gerekli bir durumdur. Bu tekniklerle ilgili bilginin olmaması durumunda, o sanat eserinin hiçbir şey ifade etmeyeceği intimali daha kuvvetli olmaktadır. Bu tekniklerle ilgili bilginin olduğu durumda, teknik ve profesyonel bir değerlendirme mümkün olmaktadır. Bu modelin profesyonel bilgiye dayalı olduğu için, yaşam tarzı, zevkler ve ilgi duyulan alanlar değerlendirmeği etkilememesi gerekmektedir. Değerlendirmelerin bilgi ve mantık çerçevesinde, duygusal yönün etkisi altında kalınmadan yapılması gerekmektedir.

Önerilen her iki model değerlendirmeyi yapacak olan kişinin ve değerlendirmesi yapılacak olan nesnenin durumuna bağlı olaraktan modellerde farklı şekillerde yapılabilmektedir. Bu modellere göre değişiklik gösteren şekiller birincisi birinci model için geçerli, ikincisi ise ikinci model için geçerli olan bir durumdur. Bunlar:

1) Öznenin nesneye katılımı sonucu bir değerlendirme

2) Öznenin nesneyle arasında bir mesafe olma sonucu bir değerlendirme

Öznenin nesneye katılımı sonucu bir değerlendirmede, özne isteğine göre kendini o nesne veya esere katarak, kendini onun bir parçası olarak görerek ve özne ile nesne arasındaki mesafeyi kaldırarak bir değerlendirme yapmaktadır. Bu şekilde bir değerlendirme, İçgüdüsel İnsan Kodlarına Dayalı Özgür Çevre Estetik Modeline hitap eden bir değerlendirme olmaktadır ve tamamen özgür bir şekilde öznenin, nesne ile duygusal bağ kurarak tercih edilmektedir.

Öznenin nesneyle arasında bir mesafe olma sonucu bir değerlendirme, daha çok Profesyonel Çevre Estetiği Modeline hitap etmektedir. Bazı sanat eseri tablolarda tuval üzerine hızlı ve şekilsiz fırça darbeleri (hareketleri) ile bir çalışma yapmak bir teknik olarak geçerli olmaktadır. Çalışmanın bittiğinde ise, yakından bu esere bakıldığında fırça izleri ve oradaki renkler anlamsız gözükebilir ama araya mesafe koyduğumuzda bu fırça izleri ve renkler daha bütün gözükmektedirler. Bu gibi durumlarda mesafe olmadan bir değerlendirmenin yapılması zor ve yanlış olabilir. Verilen örnek nesnenin yapılmış olan tekniği ile alakalı olan bir durumdur ve aradaki mesafenin olması zorunlu olmaktadır.

\section{Biyofili ve Modellerin Bağlantısı}

İnsan var olduğu günden itibaren doğa ile iç içe olmuştur. Geçmişten günümüze de hayatını, doğa içerisinde tecrübe edindiklerinden esinlenerek şekillendirmeye çalışmıştır. İnsan yaşamı ve devamlılığını korumanın doğa ile arasındaki ilişkiden geçtiğinin farkına varmıştır. Bu sebepten doğa ile arasındaki bağı, gerek fiziksel, gerek duygusal, doğayı daha iyi tanımaya çalışarak güçlendirmeye çalışmıştır. Bu bağ insan evrimi sürecinde, inşaların yaşam belleğinde bugüne kadar korunmuş ve taşınmıştır. Bugün biz bu bağı tanımladığımız ‘Biyofili’ kavramı olarak geçerli bulmaktayız. Biyofilik tasarımını destekleyenlerin isim babalarının üzerinde durdukları önemli nokta, insanın evrimsel süreci içerisinde hayatta kalma çabası ve üretme başarısı ve bunun yaşamın birebir kendisi ile ve kurduğu bağ ile ilgili olmasıdır, bu bağ doğaya yakınlık hissidir ve her insan için ortak bir duygudur (Bayraktaroğlu, 2014, s. 35; Brown vd. 2013; Ikei vd. 2014; Nieuwenhuis, vd. 2014). Bu ortak duygu üzerine insan belleğinde kodlanmış ve yaşayarak oluşup güçlenmiş bir bağ, önerilen modellerin ana fikri, yani 'insanların 
hepsinin bir estetik değerlendirme yapma hakkına sahip olduğunu' desteklemektedir.

Estetik bir değerlendirme yapmak için bilginin gerekli olduğunu savunan modeller burada eleştirilmiştir. Aslında başka bir bakış açısından bakıldığında, bu bilgi iki şekilde tanımlana bilinir. Bu bilginin bir kısmı insanın doğa ile olan ilişkisi üzerine oluşmuş ve nesiller boyu aktarılmış ve bilinç altına yerleşmiş bir bilgidir, bir kısmı ise günümüz ve teknoloji itibariyle, profesyonel bir çaba üzerine elde edilmiş profesyonel bir bilgidir. Bu nedenle biyofili kavramına da bakıldığında doğayla ilgili bu bilgi, bağ ve ilişkinin tüm insanlarda var olduğu üzere hepsinin estetik bir değerlendirme yapma hakkına sahip olduğunu savunabiliriz.

Tüm bu örnek çalışmalarda gerek ev, gerek iş yeri, gerek günlük yaşantı, gerekse akademik hayatta biyofilinin uygulanması insanlar üzerinde olumlu etkiler ve cazibe oluşturmaktadır. Bu olumlu etkiler, insanlar bu tasarımın farkında olmadan bile geçerli olmaktadır. Eğer ki insanlar bunun farkında olmadan bile bu olumlu etkiyi yakalayabilmekteyseler, buda insan ve doğa arasındaki güçlü bir bağın olduğunun göstergesidir. Biyofili kavramı, biyofili adı altında olmasa bile insanların içinde taşıdıkları bir bağ olduğu için önerilen modellerin değerlendirmesindeki temeldir. İster İçgüdüsel İnsan Kodlarına Bağlı Özgür Çevre Estetik Modelinde ister Profesyonel Çevre Estetiği Modelinde, yapılan değerlendirmeler bu temel bağdan beslenmektedirler. Biyofilik tasarım bilindiği gibi insanın doğa içindeki yaşamına odaklanan ve insan ve doğa arasındaki iletişimi göz önünde bulunduran bir tasarım anlayışıdır. İnsan doğa içinde dolaysız olarak doğrudan doğaya maruz kalmakta ve gündelik işlerini bu koşullar altında gerçekleştirmektedir. Günlük yaşamda kullanılan mimari mekanlarında bu koşulları sağlaması açısından biyofilik tasarım büyük önem arz etmektedir. Bu mekanlarda uzmanların ikinci modele göre tasarladıkları mekanlar içgüdüsel yani birinci modele göre kullanıcı tarafından deneyimlenecektir. Bu anlamda modellerin biyofili ile ilişkisi de önem arz etmektedir. Bu açıdan yaklaşıldığından modeller bağlamda değerlendirme ve kullanıcı tatmini günlük verimlilik açısından üst düzeye ulaştığında başarıya ulaşılmış olunacaktır.

\section{Sonuç}

Carlson'nın (2009) sınıflandırdığı beş model arasında, katılım estetiği modeli dışındaki diğer dört modelin estetik deneyimi ve değerlendirmeyi yapacak olan özneyi merkeze aldığı ve bir bakıma doğayı dışlayan, onun olduğu gibi algılanmasında indirgeyici davranan bir yaklaşım ve bakış açısına sahip olduğu söylenebilir. Bu dört model insan merkezcil bir yaklaşıma neden olabilmektedir. Günümüzde yaşanan çevre sorunlarının temel nedenlerinden birisinin insan merkezcil yaklaşım olduğu söylenebilir. Önerilen yeni modellerin amaçlarından birisi de doğa ve insanın bütünlüğünü estetik değerlendirme ve yargılama yapıldığında vurgulayabilmek ve insanların estetik bir değerlendirme yaptıklarında bunun farkında olmalarına yardım etmeye çalışmaktır. İnsan yaptığı estetik değerlendirmelerde literatürde belirtildiği gibi kendini doğadan ayrı gördüğü sürece doğaya hükmeden bir bakış açısına sahip olabilmektedir ve bu insanların farkındalığını azaltarak insan-doğa sorunlarının artmasına yol açabilmektedir.

Tüm modeller değerlendirildikten sonra, biyofili hipotezi de göz önünde bulundurulduğunda, bir anlamda bir insanın yaşadığı doğa ve çevreyle ilgili olarak ne bağlamda yorum yapma hakkına sahip olduğu sorusu akla gelebilir. İnsanın içgüdüsel ve tecrübelere dayalı bilgiler ışığında mı profesyonel bir eğitime dayalı olarak elde edilen bilgiler bağlamında mı yorum yaptığı sorusunu sormak yerinde görünmektedir. Aslında önerilen modeller bu soruda olduğu gibi insanı bir tercih yapmak zorunda bırakmamaktadır ve her iki şekilde de yorum yapmayı mümkün kılmaktadır.

İnsan-doğa ilişkisi ve modellerin biyofili bağlamında ortaya çıkması Şekil 1'deki diyagramla daha net bir şekilde anlatılmaktadır. İnsan ve doğa arasındaki ilişkide fiziksel ve duygusal anlamda oluşan etkileşimler, bir bağ kurulmasına sebep olmaktadır. Bu bağ biyofili olarak adlandırılmıştır. Biyofili veya Wilson'ın (1996) dediği gibi insanın doğuştan doğaya ve cantılara olan eğilimi ve sevgisi, insanda içgüdüsel bir sezinleme ve bağ oluşturmuştur. Biyofili bağlamında var olan sezinlemenin bir kısmı insanın var oluşundan itibaren doğayla olan teması sonucu nesillerce insan belleğinde taşınmış ve bugüne kadar gelmiş kanılar olarak adlandırılabilir. Bu kanılar insanların geçmişinden, yaşadıklarından ve tecrübelerinden beslenen içgüdüsel kanılardır. Bu kanıların sonucu olarak çalışmada biyofili’nin de içgüdüsel bağının beslediği ‘İçgüdüsel İnsan Kodlarına Bağlı Özgür Çevre Estetik Modeli’ önerilmiştir. Bu model, insanla doğa arasında bir bağ varsa, bir yorum hakkının da saklı olduğu fikrini savunmaktadır. Bir çevrede var olduğunuzda, o çevreyle ilgili olumlu, olumsuz veya her ikisini birden içeren bir bağ kurduğunuz kabul edilebilir ve bu bağlamda, 
daha önce belirtilen bu bağ size özgün bir değerlendirme yapma hakkını sağlamaktadır. Bu bağ nedeniyle çevre üzerine biyofili bağlamında bir estetik değerlendirme, öznenin kendini nesneye katması ve onunla bir bütün halinde görmesiyle gerçekleşebilmektedir. Bu modele göre küçücük bir çocuğun bile doğaya maruz kaldığında gösterdiği heyecan, korku, merak, sevinç veya herhangi bir duygu, onun duygusal tepkileriyle kendisini saran doğayı yorumladığını göstermektedir.

Biyofili bağlamında doğan düşüncenin bir diğer kısmı ise profesyonel bir eğitim sonucu gelişmiş profesyonel bir bilgidir. Bu bilişsel profesyonel bilgi sonucu Profesyonel Çevre Estetiği Modeli önerilmiştir. Bu model doğa veya bizi saran çevrenin yorumlanabilmesi için üst seviyede bilgi gerektiren bir model olmaktadır. Geçmişten bugüne, insanların yaşamlarından kalan izleri tespit etmek ve yorumlayabilmek için profesyonel eğitim gerekmektedir. Bu profesyonel bilgi olmazsa bu konuyla ilgili yorum yapmak imkansız olmaktadır. Bu modelde daha rasyonel ve nitelikli bir yorum yapabilmek adına öznenin nesneden mesafeli olması gerekmektedir. Bu yorumlama ne kadar bilgi ve mantık çerçevesinde yapılırsa o kadar sağıklı bir sonuç ortaya koymaktadır. Bazı detayları göz önünde bulundurarak ileri zamanlarda bu modellerin alt başlığını oluşturan model çeşitleri geliştirilebilmektedir.

Sonuç olarak ortaya konulan modellerin, biyofilinin gelişimine ve yaygınlaşmasına katkı koyacağı düşünülmektedir. Bu bağlamda, yeni önerilen modellerin geçerliliği, literatürde kabul görmesine bağlı olarak değerlendirilebilir. Ancak, bu iki modelin öznel ve nesnel değerlendirmeyi bir arada kapsadığı için daha geçerli modeller olduğu görülmektedir.

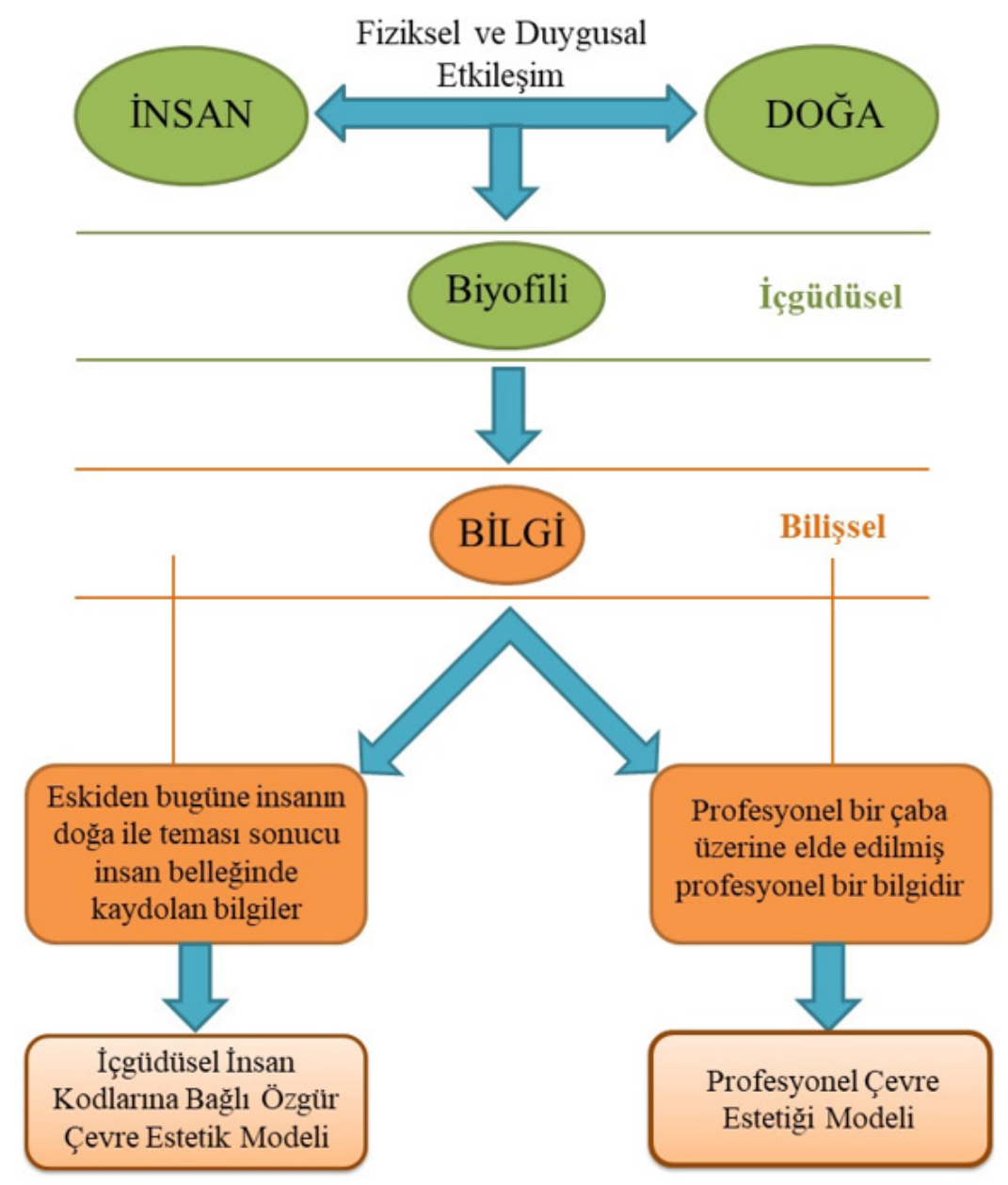

Şekil 1. Önerilen modellerin biyofili ile ilişkisi. 


\section{Teşekkür}

Katkılarından dolayı Sayın Şevin BAYRAM’a teşekkürü bir borç biliriz.

\section{Kaynakça}

Abdelaal, M.S. (2019). Biophilic campus: An emerging planning approach for asustainable innovation-conducive university. Journal of Cleaner Production, 215, 1445-1456.

Bayraktaroğlu, Ö.E. (2014). Mimarlıkta ekosistem düşüncesiyle tasarlamak (Yayımlanmamış doktora tezi). İstanbul Teknik Üniversitesi Fen Bilimleri Enstitüsü, İstanbul.

Berleant, A. (1992). The aesthetics of environment. Philadelphia: Temple University Press.

Brown, D.K., Barton, J.L. ve Gladwell, V.F. (2013). Viewing nature scenes positively affects recovery of autonomic function following acute mental stress. Environ Sci Technol, 4, 55625569.

Carlson, A. (1979). Appreciation and the natural environment. The Journal of Aesthetics and Art Criticism, 3, 267-275.

(2000). Aesthetics and the environment: The appreciation of nature, art and architecture. New York: Routledge.

(2009). Nature and landscape: An introduction to environmental aesthetics. New York: Columbia University Press.

Carlson, A. and Berleant, A. (2004). Introduction: The aesthetics of nature. In Carlson A.- Berleant A. (Ed.), The aesthetics of natural environments (p. 11-42), Canada: Boardview Press.

Carlson, A. and Lintott S. (2008). Introduction: Natural aesthetic value and environmentalism. In Carlson A.- Lintott S. (Ed.), Nature, aesthetics, and environmentalism: From beauty to duty (p. 1-22), USA: Columbia University Press.

Çorakçı, R.E. (2016). İç mimarlıkta biyofilik tasarım ilkelerinin belirlenmesi (Yayımlanmamış doktora tezi). Mimar Sinan Güzel Sanatlar Üniversitesi Fen Bilimleri Enstitüsü, İstanbul.

Dobson, A. (1993). Ecologism. In Eatwell R.- Wright A. (Ed.), Contemporary political ideologies (p. 216-238), London: Printer Publishers.

Genç, G., Selçuk, S.A. ve Beyhan.F. (2018). Biyofilik kavramının tarihi binalar bağlamında değerlendirilmesi: Tokat Mustafa ağa hamamı. The Journal of International Social Research, 58, 1307. 9581.

Gilpin, W. (1792). Three essays: On picturesque beauty, on picturesque travel, and on the sketching landscape, London: Balmire.
Gizushka özgün Türkçe blog (t.y.). Genel kültür. Erişim adresi: https://www.gizushka.com/biyofili-nedir-kelimekolik

Heerwagen, J., Orians, G. (1993). Biophilia hypothesis. Washington: Island Press.

Hepburn, R. (2004). Contemporary aesthetics and the neglect of natural beauty. In Carlson A. ve Berleant A. (Ed.), The aesthetics of natural environments (p.11-42), Canada: Boardview Press.

Heywood, A. (2007). Siyasi ideolojiler. Ankara: Liberte Yayınları.

Ikei, H., Komatsu, M., Song, C.R. (2014). The physiological and psychological relaxing effects of viewing rose flowers in office workers. Journal Physiol Anthropol, 33, 1-5.

Knight, R. P. (1794). The landscape. London: Bulmer.

Nieuwenhuis, M., Knight, C. and Postmes, T. (2014). The relative benefits of green versus lean office space: Three field experiments. Journal Exp. Psychol. Appl., 20, 199-214.

Price, U. (1794). An essay on the picturesque. London: Robson.

Rosley, M.S., Abdul Rahman, S.R. and Lamit, H. (2014). Biophilia theory revisited: Experts and non-experts perception on aesthetic of ecological landscape. Procedia-Social and Behavioral Sciences, 153, 349-362.

Saito, Y. (1999). Everyday aesthetics. USA: Oxford University Press.

Sanchez, J.A. Ikaga, T. and Sanchez, S.V. (2018). Quantitative improvement in workplace performance through biophilic design: A pilot experiment case study. Energy and Buildings, 177, 316-328.

Sepänmaa, Y. (1986). The beauty of environment: A general model for environmental aesthetics. USA: Environmental Ethics Books.

Tuan, Y. F. (1974). Topohilia, a study of environmental perception, attitudes, and values. USA: Columbia University Press.

Ulrich, R. S. (1993). Biophilia, biophobia and natural landscape. In Kellert S.R. and Wilson E.O. (Ed.), Biophilia Hypothesis (p. 73-137), USA: Island Press.

Van den Berg, A.E., Hartig, T. and Staats, H. (2007). Preference for nature in urbanized societies: Streets, restoration, and the pursuit of sustainability. Journal of Social Issues, 63, 88 89.

Anthropocene. (t.y.). Wikipedia. Erişim adresi: https:// en.wikipedia.org/wiki/anthropocene 
Wilson, E. O. (1984). Biophilia. USA: Harvard University Press.

(1996). In search of nature. Washington: Harvard University Press.

Zhang, W., Goodale, E. and Chen, J. (2014). How contact with nature affects children's biophilia, biophobia and conservation attitude in China. Biological Conservation, $177,109-116$. 